\title{
An Independent Study Course by an Academic Library Department: Teaching with the Gems of Special Collections
}

\begin{abstract}
Special collections in academic libraries provide rich learning environments for student engagement. This article describes the introduction of an independent study course by an academic library department as a high-impact educational practice supporting undergraduate research. Under the supervision of the faculty archivist, the student in this study was challenged to discover and research "gems," unusual or significant items, on a topic of her choosing. She selected three works related to James Joyce's Finnegans Wake, showcasing her research at the university's Student Faculty Research Symposium and creating a library display as her final project. This case study explores background information and describes the course, its inception, and the student's project. It includes a discussion of benefits and challenges, transferability, scalability, and the application of a constructivist approach to teaching and learning. Limitations and further research are also included in this study.
\end{abstract}

\section{Introduction}

This case study describes the successful introduction of an independent study course in an academic library's special collections, with the library department awarding the credits. Independent study complements other modes of library instruction, offering a compelling alternative to existing credit-bearing courses, information literacy sessions, internships, and assistantships. In this case, the student was challenged to discover and research "gems," unusual or significant items, on a topic of her choosing. She selected three works related to James Joyce's Finnegans Wake, showcasing her research at the university's Student Faculty Research Symposium and creating a library display as her final project. This case study presents background information, including a literature review. It describes the course, its inception, the student's project, and the faculty archivist's assessment of student learning outcomes. Also included are a discussion of benefits and challenges, transferability, scalability, and the application of a constructivist approach to teaching and learning in academic libraries. Independent study courses in special collections are not well-documented in the literature. While further research is needed, this case study begins to address that gap. 
Beginning as an intern in the fall of 2017, the student coauthor of this case study conducted research with the faculty archivist as an independent study in the spring of 2018. The student's objectives were to discover, investigate, and document "gems" in the rare books collection. For the purposes of this article, "gems" refers to special collections items of unique cultural or historical interest as identified by the student. ${ }^{1}$ The terms "archivist" and "special collections librarian" in the literature review include curators, rare books librarians, and other cultural heritage professionals. ${ }^{2}$ The term "faculty archivist" refers to the archivist/special collections librarian who served as the instructor of the independent study. ${ }^{3}$

\section{Background}

Special collections in academic libraries are often tied to institutional archives and may include rare books, manuscripts, and personal papers, depending on the mission of the institution. ${ }^{4}$ Materials may be designated as special collections because of their condition, year of publication, monetary value, format, or association with the institution. The nature and scope of a library's special collections, along with factors such as institution size and the academic status of librarians, will determine the research possibilities that might be offered.

In this case study, the rare books collection within Slippery Rock University of Pennsylvania's library archives and special collections was the focus of the student's research. The faculty archivist applied a constructivist approach to instruction: the student created knowledge by identifying and investigating works in the collection, researching and describing her selection of items with unique cultural or historical interest. Although the project began during a student internship, this article focuses on the subsequent independent study, highlighting the efficacy of this form of instruction. Background information regarding archives and special collections instruction as well as a discussion about constructivist educational theory are included in the following literature review.

1. The term "gems" was inspired by Xi Chen in reference to hidden resources in special collections. Xi Chen, "Hidden Gems Uncovered-Discovering China Studies Special Collections in Liberal Arts Colleges in the U.S.," Journal of East Asian Libraries 160 (Feb. 2015): 54-58.

2. For a description of the wide variety of related information professionals' titles and positions, see Alice Schreyer, "What's So Special about Special Collections Librarians?" RBM 7, no. 1 (Spring 2006): 49.

3. The faculty archivist coauthor is a dual archivist/librarian as described in Mary Manning and Judy Silva, "Dual Archivist/Librarians: Balancing the Benefits and Challenges of Diverse Responsibilities," College \& Research Libraries 73, no. 2 (Mar. 2012): 164-81. Educated as an archivist and librarian, she received no formal training in special collections librarianship. For a discussion on the lack of rare books related curriculum in library science master's degree programs, see Deirdre Stam, "Bridge That Gap! Education and Special Collections," RBM 7, no. 1 (Spring 2006): 25.

4. Steven K. Galbraith and Geoffrey D. Smith, Rare Book Librarianship: An Introduction and Guide (Santa Barbara, CA: Libraries Unlimited, 2012), 5. 


\section{Literature Review}

\section{Instruction in Academic Libraries, Archives, and Special Collections}

Academic librarians have long taught information literacy skills to undergraduates via "one-shot" instruction sessions. ${ }^{5}$ The Association of College $\&$ Research Libraries' (ACRL) Framework for Information Literacy for Higher Education includes guidelines that support this and other instructional formats in academic libraries. ${ }^{6}$ While academic archivists have not been engaged in information literacy instruction as extensively as librarians, primary source instruction has increased during the past 20 years and is supported by the literature. Marcus Robyns and Peter Carini laid the groundwork regarding archivists as educators. ${ }^{7}$ RBM: A Journal of Rare Books, Manuscripts, \& Cultural Heritage devoted a 2006 issue to education using special collections, in which Stam, Smith, Schreyer, and others discuss teaching with primary sources. ${ }^{8}$ Some years later, Reynolds presented the state of special collections instruction in Association of Research Libraries (ARL). ${ }^{9}$

Recently published handbooks support primary source instruction by archivists and special collections librarians. Bahde, Smedberg, and Taormina's Using Primary Sources: Hands-on Instructional Exercises; Prom and Hinchliffe's Teaching with Primary Sources; and Mitchell, Seiden, and Taraba's Past or Portal? Enhancing Undergraduate Learning through Special Collections and Archives all represent valuable resources to support teaching. ${ }^{10}$ These texts provide information professionals with exercises that may be adopted or customized rather than having to create their own. Additionally, pedagogy is addressed by Bahde, Smedberg, and Taormina, while Prom and Hinchliffe contextualize primary source literacy within broader educational frameworks. These handbooks are among the recommendations included in the 2017 Guidelines for Primary Source Literacy, created by a joint task force of the ACRL Rare Books and Manuscript Section (RBMS) and the Society of American Archi-

5. John Walsh, Information Literacy Instruction: Selecting an Effective Model (Oxford, UK: Chandos, 2011)

6. Framework for Information Literacy for Higher Education (Chicago, IL: Association of College \& Research Libraries, 2015).

7. Marcus Robyns, "The Archivist as Educator: Integrating Critical Thinking Skills into Historical Research Methods Instruction," The American Archivist 64, no. 2 (Fall 2001): 363-84; Peter Carini, "Archivists as Educators: Integrating Primary Sources into the Curriculum," Journal of Archival Organization 7, no. 1/2 (Jan.-June 2009): 41-50; for a summary of the literature regarding archivists as educators, see Evgenia Vassilakaki and Valentini Moniarou-Papaconstantinou, "Beyond Preservation: Investigating the Roles of Archivists," Library Review 66, no. 3 (2017): 110-26.

8. Stam, "Bridge That Gap!” 16-30; Steven E. Smith, "From 'Treasure Room' to 'School Room': Special Collections and Education," RBM 7, no. 1 (Spring 2006): 31-39; Schreyer, "What's So Special about Special Collections Librarians?" 49-54.

9. Matthew C. Reynolds, "Lay of the Land: The State of Bibliographic Instruction Efforts in ARL Special Collections Libraries," RBM 13, no. 1 (Spring 2012): 13-26.

10. Using Primary Sources: Hands-on Instructional Exercises, eds. Anne Bahde, Heather Smedberg, and Mattie Taormina (Santa Barbara, CA: ABC-CLIO, 2014); Teaching with Primary Sources, eds. Christopher Prom and Lisa Janicke Hinchliffe (Chicago, IL: Society of American Archivists, 2016); Past or Portal? Enhancing Undergraduate Learning through Special Collections and Archives, eds. Eleanor Mitchell, Peggy Seiden, and Suzy Taraba (Chicago, IL: Association of College \& Research Libraries, 2012). 
vists (SAA).${ }^{11}$ The Guidelines delineate four core ideas in support of primary source literacy: analytical, ethical, and theoretical concepts, as well as practical considerations. Additionally, the Guidelines include learning objectives, a glossary of terms, an annotated bibliography, and related resources.

The ACRL Competencies also include guidelines for special collections professionals:

Special collections professionals participate in and contribute to the educational and research missions of their institutions as well as to the learning that occurs within their extended communities. They support and facilitate learning, teaching, and research by focusing on the use of special collections. They develop knowledge of their collections in order to instruct users in the value of appropriate resources and to assist users in locating relevant materials. They teach, write, and present based on materials in their collections. They may use or support a variety of teaching methods and are aware of and respond to changing trends in education, scholarship, and learning. ${ }^{12}$

Numerous case studies showcase the work of archivists and special collections librarians providing instruction. Anderberg shares her experience teaching science undergraduates with primary sources, as do Brown, Losoff, and Hollis. ${ }^{13}$ Martin-Bowtell and Taylor highlight art instruction in special collections. ${ }^{14} \mathrm{McCoy}$ teaches with primary source letters in the China Mission Project, while Gardner and Pavelich share their approach to teaching with ephemera. ${ }^{15}$ Anne Bahde takes special collections to the campus classroom, and Morris, Mykytiuk, and Weiner address the need for archival literacy among history students. ${ }^{16}$ Schmiesing and Hollis

\footnotetext{
11. ACRL RBMS-SAA Joint Task Force on the Development of Guidelines for Primary Source Literacy, Guidelines for Primary Source Literacy (2017), available online at https: / www2.archivists.org/ standards/guidelines-for-primary-source-literacy [accessed 6 March 2019].

12. American Library Association, "Guidelines: Competencies for Special Collections Professionals" (2017).

13. Lindsay Anderberg, "STEM Undergraduates and Archival Instruction: A Case Study at NYU Polytechnic School of Engineering,” The American Archivist 78, no. 2 (Fall/Winter 2015): 548-66; Amanda H. Brown, Barbara Losoff, and Deborah R. Hollis, "Science Instruction through the Visual Arts in Special Collections," portal: Libraries \& the Academy 14, no. 2 (Apr. 2014): 197-216.

14. Adele Martin-Bowtell and Rebekah Taylor, "A Collaborative Approach to the Use of Archives in Information Literacy Teaching and Learning in an Arts University," Art Libraries Journal 39, no. 4 (2014): $27-32$.

15. Michelle McCoy, "The Manuscript as Question: Teaching Primary Sources in the Archives-the China Missions Project," College \& Research Libraries 71, no. 1 (Jan. 2010): 49-62; Julia Gardner and David Pavelich, "Teaching with Ephemera," RBM 9, no. 1 (Spring 2008): 86-92.

16. Anne Bahde, "Taking the Show on the Road: Special Collections Instruction in the Campus Classroom," RBM 12, no. 2 (Fall 2011): 75-88; Sammie Morris, Lawrence J. Mykytiuk, and Sharon A. Weiner, "Archival Literacy for History Students: Identifying Faculty Expectations of Archival Research Skills," The American Archivist 77, no. 2 (Fall/Winter 2014): 394-424.
} 
describe a collaboration between a professor of German and a special collections librarian. ${ }^{17}$

These researchers are not alone in this collaborative approach to instruction with classroom faculty. Indeed, the literature addresses the concept of special collections instruction primarily as a team effort, with classroom faculty serving as the instructors of record. Increasingly, however, librarians and archivists are beginning to teach credit-bearing courses.

\section{Credit-Bearing Courses in Academic Libraries, Archives, and Special Collections}

In addition to one-shot instruction sessions, academic librarians are increasingly teaching credit-bearing courses in support of information literacy. ${ }^{18}$ Credit-bearing courses taught by archivists and special collections librarians have also begun to be documented in the literature. Pablo Alvarez, a special collections librarian, shares three case studies about introducing rare books into the undergraduate curriculum. Initially done in partnership with teaching faculty, he began teaching a credit-bearing class in 2006. ${ }^{19}$ Sandra Roff expands the information literacy program at Baruch College by adding her Archives, Documents, and Hidden History course to the library's curriculum. ${ }^{20}$ Laura Clark Brown co-teaches a freshman seminar using primary sources. ${ }^{21}$ Nimer and Daines created and teach a course to develop undergraduates' archival literacy skills, while Rick Ewig teaches critical thinking skills in his archival research methods course. ${ }^{22}$ Germek and Lane teach undergraduate book history courses at Monmouth University and the University of Wyoming respectively. ${ }^{23}$

17. Ann Schmiesing and Deborah Hollis, "The Role of Special Collections Departments in Humanities Undergraduate and Graduate Teaching: A Case Study," portal: Libraries \& the Academy 2, no. 3 (July 2002): 465-80.

18. Jane Kemp, "Isn't Being a Librarian Enough? Librarians as Classroom Teachers," College \& Undergraduate Libraries 13, no. 3 (2006): 21; Nadine Cohen, et al., "A Survey of Information Literacy Credit Courses in US Academic Libraries," Reference Services Review 44, no. 4 (2016): 564-82; Karen Sobel, Peter Ramsey, and Galin Jones, "The Professor-Librarian: Academic Librarians Teaching Credit-Bearing Courses," Public Services Quarterly 14, no. 1 (Jan.-Mar. 2018): 1-21; Yvonne Mery, Jill Newby, and Ke Peng, "Why One-Shot Information Literacy Sessions Are Not the Future of Instruction: A Case for Online Credit Courses," College \& Research Libraries 73, no. 4 (July 2012): 366-77.

19. Pablo Alvarez, "Introducing Rare Books into the Undergraduate Curriculum," RBM 7, no. 2 (Fall 2006): 94-103.

20. Sandra Roff, "Archives, Documents, and Hidden History: A Course to Teach Undergraduates the Thrill of Historical Discovery Real and Virtual," History Teacher 40, no. 4 (Aug. 2007): 551-58.

21. Laura Clark Brown, "Chapel Hill Diarist: The Evolution of a Theory and the Practice of Immer sion in Primary Sources," Journal for the Society of North Carolina Archivists 6, no. 2 (Winter 2009): 5-25.

22. Cory L. Nimer and J. Gordon Daines, "Teaching Undergraduates to Think Archivally," Journal of Archival Organization 10, no. 1 (Jan.-Mar. 2012): 4-44; Rick Ewig, "When Did Sacajawea Die Anyway? Challenging Students with Primary Sources," in Past or Portal, Enhancing Undergraduate Learning Through Special Collections and Archives, eds. Eleanor Mitchell, Peggy Seiden, and Suzy Taraba (Chicago, IL: American Library Association, 2012), 186-91.

23. George Germek, "Starting Almost from Scratch: Developing Special Collections as a Teaching Tool in the Small Academic Library," College \& Undergraduate Libraries 23, no. 4 (2016): 400-13; Anne Marie Lane, "Books IN History; Books AS History: Teaching Undergraduates in the Toppan Rare books Library, University of Wyoming," in Past or Portal, Enhancing Undergraduate Learning Through Special Collections and Archives, eds. Eleanor Mitchell, Peggy Seiden, and Suzy Taraba (Chicago, IL: American Library Association, 2012), 219-24. 


\section{Internships in Academic Libraries, Archives, and Special Collections}

Special collections internships represent a comparatively underexplored niche. Library internships broadly are described by a number of researchers, and archival internships are described in great detail by Bastian and Webber. ${ }^{24}$ Madway addresses graduate internships for library and information science students. ${ }^{25}$ Kopp and Murphy, however, are among the few researchers to address undergraduate internships in special collections. They describe Brigham Young University's undergraduate internship program, which is well established and may serve as a model for other institutions. ${ }^{26}$ Noting the importance of creating meaningful learning experiences and the opportunity for career exploration, Kopp provides a 2019 update of this recently revised program. ${ }^{27}$

The American Library Association (ALA) has established internship program standards for undergraduates in academic libraries. ${ }^{28}$ Internships are commonly designated as high-impact practices that increase student retention. ${ }^{29}$ The Association of American Colleges and Universities (AAC\&U) defines the high impact provided by internships as a direct experience in a work setting that provides the benefit of mentoring from professionals in the field. ${ }^{30}$ These practices, according to the $A A C \& U$, increase student engagement, which in turn leads to improved student learning outcomes and retention.

\section{Student Assistantships in Academic Libraries, Archives, and Special Collections}

Mestre and Lecrone describe the learning opportunities provided to student workers at the University of Illinois at Urbana-Champaign as a result of elevat-

\footnotetext{
24. Candice Dahl, "Creating Undergraduate Internships for non-LIS Students in Academic Libraries," Collaborative Librarianship 3, no. 2 (2011): 73-78; Kayo Denda and Jennifer Hunter, "Building 21st Century Skills and Creating Communities: A Team-Based Engagement Framework for Student Employment in Academic Libraries," Journal of Library Administration 56, no. 3 (2016): 251-65; Katy Kelly, Colleen Hoelscher, and Heidi Gauder, "Results for Resumes: Managing Undergraduate Library Interns," Library Leadership \& Management 28, no. 4 (2014): 1-17; Marta K. Lee, Mentoring in the Library: Building for the Future (Chicago, IL: American Library Association, 2011); Jennifer E. Nutefall, "Structuring a Successful Instruction Internship," College \& Undergraduate Libraries 19, no. 1 (2012): 80-94; Jeannette A. Bastian and Donna Webber, Archival Internships: A Guide for Faculty, Supervisors, and Students (Chicago, IL: Society of American Archivists, 2008).

25. Lorraine Madway, "Archival Internships: Creating Real World Learning Beyond the Classroom," Kansas Library Association College and University Libraries Section Proceedings 1, no. 1 (2011): 48-56.

26. Maggie G. Kopp and John M. Murphy, "Mentored Learning in Special Collections: Undergraduate Archival and Rare Books Internships." Journal of Library Innovation 3, no. 2 (2012): 50-62.

27. Maggie G. Kopp, "Internships in Special Collections: Experiential Pedagogy, Intentional Design, and High-Impact Practice," RBM 14, no. 2 (Spring 2019): 12-27.

28. American Library Association (2006).

29. Saori W. Herman, "Positive Correlation between Academic Library Services and High-Impact Practices for Student Retention," Evidence Based Library \& Information Practice 11, no. 1 (2016): 85-87.

30. George D. Kuh, High Impact Educational Practices: What They Are, Who Has Access to Them, and Why They Matter (Washington, DC: Association of American Colleges and Universities, 2008).
} 
ing the level of assistantships. ${ }^{31}$ Sauceda describes the assistantship program at Rutgers, drawing parallels to internship and independent study models that tend to be "open-ended [and] structured around the needs of the librarian or archivist and the student." 32 According to Sauceda, the advantage of assistantships is the extension beyond a semester to an academic year, allowing for greater depth of student learning. Whatever the approach, he and other contemporary researchers make the case for the importance of student mentoring in academic libraries. ${ }^{33}$ "Whether librarians and archivists have faculty status or not ... they should be encouraged to engage with students directly rather than only through a member of the teaching faculty." ${ }^{34}$ The topic of faculty status is addressed later in this article.

\section{Archivists' and Librarians' Preparation as Educators}

In addition to the question of faculty status, archivists and librarians may lack formal teaching experience. In fact, their educational preparedness represents an ongoing theme in the literature. ${ }^{35}$ If archivists and special collections librarians are going to teach, continuing education is often the formal setting for learning skills, as masters of library science programs have not historically included this preparation. ${ }^{36}$ Anne Marie Lane provides practical advice about continuing education for information professionals entering the classroom. ${ }^{37}$ Like classroom faculty, archivists and librarians require knowledge of appropriate pedagogy. Teaching and learning theories may be identified and implemented to support effective instruction. Taking advantage of the materiality of primary sources in archives and special collections, constructivism and its related subtheories are frequently referenced in the literature. This pedagogical lens as applied to instruction in libraries, archives, and special collections is outlined in the next section.

\footnotetext{
31. Lori S. Mestre and Jessica M. Lecrone, "Elevating the Student Assistant: An Integrated Development Program for Student Library Assistants," College \& Undergraduate Libraries, 22, no. 1 (2015): $1-20$.

32. Jonathan Sauceda, "Arranging 'The Library of Babel': Special Collections, Undergraduate Research, and Librarian Engagement," portal: Libraries and the Academy 18, no. 2 (Apr. 2018): 402.

33. Pamela Hayes-Bohanan, "Librarian Mentoring of an Undergraduate Research Project," Journal of Library Innovation 4, no. 1 (2013): 21-28; Jon R. Hufford, "Librarians as Mentors in an Undergraduate Research Program," Journal of Library Administration 57, no. 7 (Oct. 2017): 776-88; Todd J. Wiebe, “The Library and Undergraduate Research in the Liberal Arts: Present Contributions and Future Opportunities," Undergraduate Libraries 23, no. 3 (July-Sept. 2016): 223-51.

34. Sauceda, "Arranging 'The Library of Babel'," 394.

35. Kemp, "Isn't Being a Librarian Enough?" 10; Michelle Reale, "Critical Pedagogy in the Classroom: Library Instruction That Gives Voice to Students and Builds a Community of Scholars," Journal of Library Innovation 3, no. 2 (Sept. 2012): 80-88.

36. Marta Bladek and Karen Okamoto, "What's Theory Got to Do with It? Applying Educational Theory and Research to Revamp Freshman Library Workshops," College \& Undergraduate Libraries 21, no. 1 (Jan.-Mar. 2014): 20.

37. Lane, "Books IN History; Books AS History," 219-20.
} 


\section{Constructivist Learning Theory in Academic Libraries, Archives, and Special Collections}

Cooperstein and Kocevar-Weidinger present a constructivist approach to academic library instruction, providing background information and noting that learning begins with "a question, a case, or a problem." ${ }^{38}$ Maryellen Allen adds her support for this pedagogical method to online information literacy instruction. She traces the roots of constructivism to Piaget, defining it as an approach in which "the learner tak[es] an active role in the learning process while the instructor serves as more of a facilitator or guide." 39 The ACRL Framework for Information Literacy codifies a constructivist approach, identifying six frames for information literacy: 1) authority is constructed and contextual; 2) information creation is a process; 3 ) information has value; 4) research as inquiry; 5) scholarship as conversation; and 6) searching as strategic exploration. ${ }^{40}$

Constructivism also appears in the archives and special collections literature. Maypole and Davies conduct a phenomenological qualitative study of undergraduate history students using primary sources within a constructivist framework. ${ }^{41}$ Silvia Vong applies a constructivist lens to teaching undergraduates with special collections in a course she designed and teaches. ${ }^{42}$

Subsets of constructivism include active learning, experiential learning, inquirybased learning, problem-based learning, and discovery learning. ${ }^{43}$ Active learning, frequently referenced as a teaching strategy in the archival literature, is defined as "learning that solicits student participation, whether in group work, class discussion, or an individual project requiring more than passive digestion of a lecture." ${ }^{44}$ Yakel and Malkmus place active learning firmly within the constructivist framework, applying it to archival instruction and tracing its application as a teaching method to the $1970 \mathrm{~s} .{ }^{45}$ Brown, Losoff, and Hollis use active learning techniques in their work with STEM (Science, Technology, Engineering and Mathemat-

38. Susan E. Cooperstein and Elizabeth Kocevar-Weidinger, "Beyond Active Learning: A Constructivist Approach to Learning. Reference Services Review 32.2 (2004): 142.

39. Maryellen Allen, "Promoting Critical Thinking Skills in Online Information Literacy Instruction Using a Constructivist Approach," College \& Undergraduate Libraries 15, no. 1-2 (2008): 30.

40. ACRL, Framework for Information Literacy (2015).

41. Joanne Maypole and Timothy Gray Davies, "Students' Perceptions of Constructivist Learning in a Community College American History II Survey Course," Community College Review 29, no. 2 (Fall 2001): $54-79$.

42. Silvia Vong, "A Constructivist Approach for Introducing Undergraduate Students to Special Collections and Archival Research," RBM 26, no. 2 (Fall 2016): 148-71.

43. Allen, "Promoting Critical Thinking Skills in Online Information Literacy Instruction," 31.

44. Schmiesing and Hollis, "The Role of Special Collections Departments in Humanities Undergraduate and Graduate Teaching," 470.

45. Elizabeth Yakel and Doris Malkmus, "Contextualizing Archival Literacy," in Teaching with Primary Sources, eds. Christopher J. Prom and Lisa Janicke Hinchliffe (Chicago, IL: Society of American Archivists, 2016), 5-67. 
ics) students in special collections and provide background information on this pedagogical approach. ${ }^{46}$ Tresa Randall describes active learning projects she uses to teach dance history with primary sources. ${ }^{47}$ Passoneau and Christian employ active learning techniques in their qualitative study on archival education and outreach to sororities and fraternities. ${ }^{48}$ Morris, Chute, and Swain devote a section of their teaching guide to active learning, describing it as problem-based and student centered..$^{49}$

Apedoe, Walker, and Reeves, along with Hepworth and Walton, describe inquirybased learning in academic libraries, as does James Marcum..$^{50}$ Citing Postman and Weingartner's Teaching as a Subversive Activity, Barbara Rockenbach describes inquiry-based learning as a method that "places the students at the center of learning and the teacher as a guide through the inquiry process." ${ }^{51}$ Rockenbach offers three case studies about teaching undergraduates with primary sources.

Experiential learning is referenced less frequently in the literature and is most often linked to internships, both in libraries and in archives. ${ }^{52}$ Experiential learning focuses on practice over theory and has been defined as an educational approach emphasizing personal experience more than learning from books and secondary sources..$^{53}$ Johnson and Harreld build on Kolb's research on experiential learning theory, focusing on learning outcomes in their discussion of mentoring undergraduate students. ${ }^{54}$

46. Brown, Losoff, and Hollis, "Science Instruction Through the Visual Arts in Special Collections," 199.

47. Tresa Randall, "Enlivening Dance History Pedagogy Through Archival Projects," Journal of Dance Education 12, no. 1 (2012): 7-13.

48. Sarah Passoneau and Michele Christian, "Participant Learning in an Archival Education and Outreach Program to Fraternities and Sororities: An Implementation of Evidence-Based Librarianship and Information Science," RBM 14, no. 2 (Fall 2013): 92-110.

49. Sammie L. Morris, Tamar Chute, and Ellen Swain, "Teaching with Archives: A Guide for Archivists, Librarians, and Educators," in Teaching with Primary Sources, eds. Christopher J. Prom and Lisa Janicke Hinchliffe (Chicago, IL: Society of American Archivists, 2016): 69-136.

50. Xornam S. Apedoe, Sally E. Walker, and Thomas C. Reeves, "Integrating Inquiry-based Learning into Undergraduate Geology,” Journal of Geoscience Education 54, no. 3 (May 2006): 414-21; Mark Hepworth and Geoff Walton, Teaching Information Literacy for Inquiry-Based Learning (Oxford, UK: Chandos Publishing, 2009); James Marcum, "The Library as Inquiry Learning System: Defining the Issues," College \& Undergraduate Libraries 16, no. 4 (Oct. / Dec. 2009): 358-62.

51. Barbara Rockenbach, "Archives, Undergraduates, and Inquiry-Based Learning: Case Studies from Yale University Library," The American Archivist 74, no. 1 (Spring/Summer 2011): 299.

52. Kelly, Hoelscher, and Gauder, "Results for Resumes," 1-17; Bastian and Webber, Archival Internships.

53. Denda and Hunter, "Building 21st Century Skills and Creating Communities," 251-65; Amy York, Christy Groves, and William Black, "Enriching the Academic Experience: The Library and Experiential Learning," Collaborative Librarianship 2, no. 4 (2010): 193.

54. Benjamin A. Johnson and Donald J. Harreld, "Nurturing Independent Learning in the Undergraduate Student in History: A Faculty-Student Mentoring Experience," Mentoring \& Tutoring: Partnership in Learning 20, no. 3 (Aug. 2012): 361-78. 
Clearly within the constructivist framework, special collections librarians and archivists have an array of pedagogical options with which to frame their teaching. Constructivism, including its numerous subtheories, appears at the center of instructional theory in the literature.

The professional literature addresses instruction in libraries, archives, and special collections at length. Credit-bearing courses, which are increasingly being taught in these areas, expand the opportunities already provided by internships, assistantships, and other forms of mentoring. A variety of learning theories, particularly constructivism and its subtheories, are also documented by the literature. What are not found are opportunities for undergraduates to engage in credit-bearing independent study in academic libraries' special collections. The Gems Project addresses this gap, applying a constructivist approach to a library department's independent study course.

\section{The Gems Project}

\section{Background}

For years, Special Collections in Slippery Rock University of Pennsylvania's Bailey Library sat largely dormant. Used mainly for events, the occasional requests for books from the collection were handled by the reference librarian on duty. The researcher was informed about safe handling, seated in the reference room, and left alone under the librarian's watchful eye. There were no special collections instruction sessions, courses, internships, or independent study opportunities for students.

All of this began to change with the university's renovation of a new space for special collections, adjacent to the university archives, in 2016. The office of the archivist was positioned in this inviting new area, and her purview expanded administratively to include special collections. As the faculty archivist assessed and rearranged the existing collection into themed subcollections, opportunities for instruction and student engagement began to emerge. Academic faculty with whom she had formerly collaborated in the archives now began to incorporate student research and instruction in Special Collections.

Internships, which had been confined primarily to Archives, began being offered in Special Collections as well. The first intern, Barbara, earned three credits for the fall 2017 semester. This internship also included a stipend. Besides the usual duties of shelving, shelf-reading, and processing incoming books, Barbara also began to explore and evaluate the rare books collection. Because the entire collection had been so long neglected, the faculty archivist was curious about the holdings and their potential research value. Barbara shared this curiosity and the Gems Project was born. 


\section{LIBR 490: Independent Study at Slippery Rock University of Pennsylvania}

Following her fall 2017 internship, Barbara became the Library Department's first independent study student the following spring semester. While the library's course offerings had not previously included independent study, as an aspiring rare books librarian, Barbara requested this opportunity, with the faculty archivist as her instructor. The library faculty member embraced the prospect of continuing to support Barbara's research, while championing the department's expanding course offerings to include independent study.

The Library Department was able to expedite approval of the new course through the university curriculum committee, as library faculty members were already teaching credit-bearing courses. ${ }^{55}$ Library Department faculty at Slippery Rock University of Pennsylvania are tenure-track, enjoying the same status as teaching faculty in academic departments. All are covered by the same collective bargaining agreement with the Pennsylvania State System of Higher Education.

The year before, the Library Department had received approval to reinstate the "LIBR" course code, which had been on hiatus since the termination of the university's library science degree program many years earlier. The existing information literacy courses were recoded as "LIBR," effectively acknowledging the teaching done by library faculty. When Barbara's request came to take a library-based independent study, the department was well-positioned to offer it.

The faculty archivist created a syllabus specific to the Gems Project, but general enough to support future topics. Included in the syllabus are weekly readings from Galbraith and Smith's Rare Book Librarianship, as well as supplemental readings from the RBMS Discussion List. ${ }^{56}$ Student learning outcomes and competencies are also included in the syllabus, and the student created her own learning objectives as well. The assigned learning outcomes included "the student will identify a subset of books from Bailey Library's Special Collections and conduct research on their intellectual value including rarity, author's significance, and historical or cultural context.". ${ }^{57}$

The student and the faculty archivist met on a weekly basis to discuss the readings and the direction of the project. Barbara maintained a weekly log of her research

55. A one-credit information literacy course has been taught for many years, with the more recent addition of a three-credit course taught by library faculty. The latter one-credit course is currently required by the Psychology Department for their majors.

56. Galbraith and Smith, Rare Book Librarianship; RBMS Discussion List, available online at http:// rbms.info/publications/discussion_list/ [accessed 6 March 2019].

57. Instructor's syllabus. 
activities and submitted biweekly reports documenting her findings on the intellectual value and interest of specific items under consideration. She also conducted a final project of her own choice, creating an exhibit in one of Bailey Library's display cases. For extra credit, Barbara presented her findings at the university's annual Student Faculty Research Symposium in the spring of 2018.

\section{The Gems of Special Collections}

According to the ACRL Guidelines for University Library Services to Undergraduate Students, "[ $\mathrm{t}]$ he library experience of undergraduates should encourage them to seek information of personal interest." ${ }^{18}$ Schmiesing and Hollis describe students as "designers of intellectual experiences." ${ }^{59}$ Such was the case for Barbara, an English major and Gender Studies minor in her senior year at the university. She began her research process by investigating numerous Special Collections items that appealed to her for a variety of reasons including their look, age, author, subject, and/or forms. She then began to focus on items that were related to her interests as an English major. Barbara's initial review of the collection yielded several volumes of personal interest, the authors of which she had recently studied in courses related to her major. This preliminary exploration was enough to light the spark for her research plans, and she dove in with enthusiasm.

Of the handful of unique volumes Barbara researched, three James Joyce items seemed to provide the most fruitful avenue for further exploration. The items, all related to Finnegans Wake, were interesting not merely as individual volumes but in their connection to each other as well. The first of the three volumes selected was Anna Livia Plurabelle, a signed first edition published by Crosby Gaige in 1928. The second was Tales Told of Shem and Shaun, a first edition published by Black Sun Press in 1929. Both volumes were published before the completion and publication of Finnegans Wake in 1939, and they align with chapters of the completed novel. The third volume was Our Exagmination Round his Factification for Incamination of Work in Progress, published by Shakespeare and Company in 1929, a decade before the complete novel was published. This collection of essays by prominent writers and acquaintances of Joyce includes commentary by Samuel Beckett and William Carlos Williams, who had followed the serial publication of Finnegans Wake (published initially under the title $A$ Work in Progress). These three volumes became Barbara’s "gems."

After selecting the three James Joyce items, Barbara delved into more in-depth research. Along with background information on Joyce and Finnegans Wake, she

\footnotetext{
58. Association of College \& Research Libraries, Guidelines for University Library Services to Undergraduate Student (2013), available online at www.ala.org/acrl/standards/ulsundergraduate [accessed 6 March 2019].

59. Schmiesing and Hollis, "The Role of Special Collections Departments in Humanities Undergraduate and Graduate Teaching," 470.
} 
looked at the value and rarity of the three volumes, as well as how they were connected to one another through Finnegans Wake. She made comparisons to contemporary editions of the title held in the university library's general collection, reviewing biographies of Joyce and guides to reading Finnegans Wake. Further, she investigated how contemporary audiences view, use, and explore Finnegans Wake, specifically using current technology.

To determine the relative merits of the titles she selected, Barbara began her research by exploring which other American libraries held similar volumes. As the selected titles are limited edition, numbered runs, she was able to determine how many extant volumes exist nationally by searching OCLC (Online Computer Library Center). Next, she searched the listings of rare book vendors to gauge the market value of each title. ${ }^{60}$ Background information about the essay writers represented in Our Exagmination supplemented her findings.

In her research process, Barbara gained considerable insights about the oeuvre of rare books and some of the subtleties of the field. Imprints and editions; the relative value of first and second printings; signed, inscribed, or autographed copies; numbered runs; and limited editions were all vague concepts that became crystallized through her investigation. In addition to understanding the value of these items, working with rare books allowed Barbara to learn more about handling special collections materials. The project also offered the opportunity to apply concepts from professional texts and supplemental readings to her work throughout the semester.

Barbara also discovered online resources that made connections to the source material. She noted that social media and blogs have been used to explore Finnegans Wake through a contemporary lens that may help modern readers understand the notably complicated novel. A Twitter account, for example, shared the definitions of some of Joyce's lesser known or unique word choices. ${ }^{61}$ The blog Wake in Progress: Illustrations to Finnegans Wake shared a panel-by-panel digital novel created by a reader, providing visual clues to the complicated story that might help readers better comprehend the original work. ${ }^{62}$

For the Student Faculty Research Symposium, Barbara created a large poster to present her findings. The poster highlighted a few of the unique items held in Special Collections as well as how they can be used in conjunction with each other, with

\footnotetext{
60. AbeBooks, Alibris, and Amazon were consulted for rare book prices.

61. @FW_WOTD (Finnegans Wake Word of the Day), available online at twitter.com [accessed 14 February 2018].

62. Wake in Progress: Illustrations to Finnegans Wake (blog), available online at www.wakeinprogress. com/ [accessed 14 February 2018].
} 
other library resources, and with online resources including rare books databases and social media. She presented the information in one-on-one and small group conversations using the poster and a handout as the basis for sharing information (see appendix). This symposium gave her an opportunity to showcase what Slippery Rock University's Special Collections has to offer to a wide audience.

Barbara's final project for the semester was a library display featuring the three Joyce-related "gems." She included the special collections items along with Joyce volumes from the circulating collection: biographies, reading guides, and contemporary editions of some items. Including both rare books and general collection resources highlighted the enriching potential of incorporating special collections into the research process. Barbara included a copy of her symposium poster and handout in the library display to provide additional information about the featured resources.

Both the symposium presentation and the library display highlighted the importance and relevance of rare books in the educational process. They showcased what the university's Special Collections has to offer to students and faculty, and how these resources can be used in conjunction with other, more accessible materials to offer an even more robust research experience.

\section{Instructor's Role and Responsibilities}

Upon approval of the library department's new course by the university curriculum committee, the faculty archivist finalized the course syllabus, which included course assignments, a grading rubric, and course competencies. The syllabus was uploaded into D2L, the university's learning management platform, along with a dropbox for assignments and the course gradebook. As the instructor, Judy posted a student welcome message, following that with additional posts throughout the semester of likely interest to the student. These posts included information about the Mills College Summer Institute for Book and Print Technologies, how to access the RBMS electronic discussion list, the Joyce Papers in the National Library of Ireland, and the ACRL RBMS-SAA Guidelines for Primary Source Literacy. The posts provided additional fodder for the pair's biweekly discussions. These face-to-face conversations also demonstrated the student's understanding of the assigned readings and her perceptions of professional concerns as gleaned from the RBMS discussion list.

\section{Assessment of Student Learning Outcomes}

The independent study assessment protocol included the following learning outcomes. The student(s) will:

- identify a subset of books from Bailey Library’s Special Collections and conduct research on their intellectual value including rarity, author's significance, and historical or cultural context; 
- create a weekly log documenting selected titles and research methods;

- create a biweekly report of research findings;

- discuss assigned chapters of required text and topics from RBMS discussion list with course instructor;

- discuss progress and address questions with the course instructor;

- create a final project compiling the research on selected items having high intellectual and research value, describing each, and placing them into historical or cultural context. ${ }^{63}$

Grading was conducted on an ongoing basis and made available to the student via the course management platform.

\begin{tabular}{|l|l|}
\hline $\begin{array}{l}\text { TABLE } 1 \\
\text { Possible Points for Assignments }\end{array}$ \\
\hline Research log, weekly entries (13 @ 10 points each) & 130 points \\
\hline Biweekly reports on research findings (6 @ 20 points each) & 120 points \\
\hline $\begin{array}{l}\text { Readings: assigned chapters and RBMS discussion list. Discuss } \\
\text { with course instructor (8 @ 5 points each) }\end{array}$ & 40 points \\
\hline Final project & 200 points \\
\hline Attendance (30 points/week) & 420 points \\
\hline Extra credit ${ }^{\star}$ & 90 points \\
\hline $\begin{array}{l}{ }^{\star} \text { Additional credit may be earned by presenting at the Symposium for Student } \\
\text { Research, Scholarship, and Creative Achievement). }\end{array}$ \\
\hline
\end{tabular}

The grading scale is shown in table 2 .

\begin{tabular}{|c|c|}
\hline $\begin{array}{l}\text { TABLE } 2 \\
\text { Grading Scale }\end{array}$ & \\
\hline $820-910$ points & A \\
\hline $720-819$ points & $\mathrm{B}$ \\
\hline $620-719$ points & $\mathrm{C}$ \\
\hline 520-619 points & $\mathrm{D}$ \\
\hline 519 points or fewer & $\mathrm{F}$ \\
\hline
\end{tabular}

\section{Discussion}

Independent study in special collections offers unique undergraduate research opportunities. Like internships, undergraduate research is considered a highimpact practice. "The goal is to involve students with actively contested questions, empirical observation, cutting-edge technologies, and the sense of excitement that comes from working to answer important questions." ${ }^{34}$

63. Instructor's syllabus.

64. AAC\&U, "High-Impact Educational Practices" (2008), available online at https:/ / www.aacu.org/ sites/default/files/files/LEAP/HIP_tables.pdf [accessed 6 March 2019]. 


\section{Benefits and Challenges of Independent Study in Special Collections}

This case study documents the introduction of an independent study course in an academic library's special collections. The benefits of such a course to undergraduates include an opportunity to explore professional and research interests; to gain practical hands-on experience; and to add a library course credential to their undergraduate transcripts. Challenges to students include a lack of background knowledge, the rigor of conducting original research, and the self-discipline required to be successful in a semistructured learning environment.

Benefits to librarians and archivists teaching independent study include the opportunity to mentor a student conducting original research, while perhaps gaining a richer knowledge of particular holdings within collections they curate. Additionally, as the professional literature indicates a growth in instructional offerings by librarians and archivists, independent study creates the opportunity to teach on a small scale. Challenges faced by information professionals might include finding the time to prepare for, engage with, and assess the work of students, as well as the requisite knowledge of pedagogical theory.

\section{Transferability}

While Slippery Rock University was well-placed to implement the introduction of an independent study course in special collections, a number of factors might influence the transferability of such a course to other institutions. As indicated, the instructor in this case is a faculty archivist and member of the library department. As such, she and departmental colleagues are eligible to teach not only information literacy sessions but credit-bearing courses as well. This may not be the case for all academic librarians or archivists, which presents an obstacle to the implementation of this instructional model elsewhere.

Institution size is another consideration in the possible expansion of instructional offerings to include independent study. Small institutions may be insufficiently staffed to allow for one-on-one library instruction, perhaps offering larger classes instead to maximize reach (if courses are offered at all). At the same time, librarians and archivists at small institutions may have such a wide array of responsibilities that taking on additional duties might not be feasible. Similarly, information professionals at medium or large institutions may also carry workloads that do not allow for the addition of responsibilities without restructuring existing duties. In the case of faculty archivists and librarians, the expectations of service and scholarship represent a considerable investment of time and attention as well.

And finally, as indicated previously, archivists and librarians may be reluctant to teach due to a lack of preparation received in master's-level library programs. 
Further education may be required for these information professionals to become familiar with educational theory and effective pedagogy to be qualified and comfortable teaching credit-bearing courses, including independent study.

\section{Scalability}

While the introductory instance of LIBR 490 focused on special collections resources, the intentionally generic course description allows for scalability to the entire library department and its faculty: "Independent study courses give students the opportunity to pursue research and/or studies that are not part of the university's traditional course offerings. Students work one on one with faculty guidance and are typically required to submit a final paper or project as determined by the course instructor." ${ }^{55}$ The faculty archivist included the following in the initial course description: "This independent study will focus on books in Bailey Library's Special Collections. The student(s) will identify, research, describe, and place into cultural context, selected volumes of particular intellectual or research value." ${ }^{\prime 6}$ As such, the course can be offered again in its present form, with subsequent students identifying and researching their own special collections "gems." Limitations to scale may include library faculty members' willingness to teach, which might be influenced by workload or other factors.

\section{Constructivism and Independent Study}

The professional literature strongly supports a constructivist approach to teaching and learning in libraries, archives, and special collections. Subsets of constructivism-active learning, experiential learning, inquiry-based learning, problem-based learning, and discovery learning — are all documented in the literature as effective approaches to instruction. The faculty archivist in the current study drew on the ACRL Framework for Information Literacy to support a constructivist teaching approach, serving as a facilitator or guide, with the student taking an active role in the learning process. The student selected her own research topic and items from the collection and designed her own research strategy, discussing and receiving direction from the faculty archivist throughout the process.

\section{Limitations of the Current Study}

This case study focuses on a single instance of a library department's independent study; therefore, the outcomes are not generalizable. Moreover, while student learning was assessed according to the rubric included in the course syllabus, in the interest of protecting the student's anonymity neither the effectiveness of the course itself nor the instructor's teaching were assessed. The authors deem the case successful based on the student's positive learning outcomes and anecdotal

65. Instructor's syllabus.

66. Instructor's syllabus. 
evidence. That said, pre- and post-tests to determine students' information literacy skills might be appropriate as additional assessment instruments for this course.

\section{Further Research}

While librarians and archivists provide information literacy and primary source instruction, oversee internships, teach credit-bearing courses, and otherwise mentor undergraduate student learning, independent study for course credit in special collections is not well documented in the literature. The authors of the current study acknowledge that such opportunities may in fact be occurring under another name or may be offered in collaboration with academic departments in a similar model. In either case, the design and effectiveness of such courses bears exploration.

Additionally, if undergraduate independent study opportunities in libraries are developed, what impact might they have on graduate student preparedness for library science programs? Regarding the independent study described in the current article, in the event that the lone course expands to become a program, assessment of feasibility as related to instructor workload should be undertaken.

The appropriateness of constructivist learning theory to independent study also warrants additional consideration. Specifically, the effectiveness of various constructivist subtheories as applied to independent study in special collections bears further research.

\section{Conclusion}

This article documents the successful introduction of an independent study course taught by a library faculty member in special collections. An overview of academic library and archives instruction is included to provide context. Instruction in libraries, archives, and special collections includes credit-bearing courses, information literacy sessions, internships, and assistantships. Independent study opportunities in academic libraries' special collections, if they are occurring, are not well documented in the professional literature. Independent study courses present unique opportunities for undergraduate student research. Archivists and special collections librarians are encouraged to explore the possibility of offering similar learning experiences to students at their own institutions. 


\section{Appendix}

\section{Three Tales of Joyce Gems from Slippery Rock University's Special Collections \\ Barbara McIntosh}

\section{James Joyce \& A Work in Progress}

- Serial publication-sections published in various literary journals such as Transition and Transatlantic Review from 1924 to 1938 under the title $A W$ ork in Progress.

- Finally published in its entirety as Finnegans Wake in 1939.

\section{Anna Livia Plurabelle (1928)}

- Chapter of Finnegans Wake independently published as a book by Crosby \& Gaige.

- SRU holds a signed first edition of a limited printing in Special Collections.

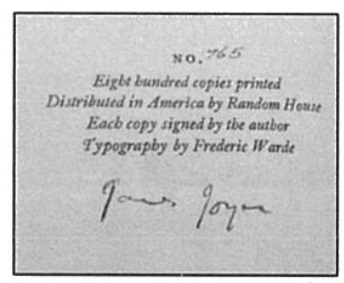

\section{Three Tales of Shem \& Shaun (1929)}

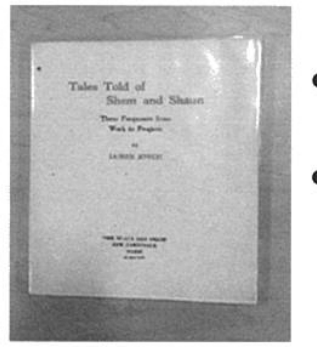

- Chapter of Finnegans Wake independently published as a book by Black Sun Press.

- SRU holds a first edition of a limited printing in Special Collections.

\section{Our Exagmination Round His Factification for Incamination of Work in Progress (1929)}

- Critical essays written by Samuel Beckett, William Carlos Williams, and other friends of Joyce who followed the publication of A Work in Progress.

- $\quad$ SRU holds one of approximately 100 copies in Special Collections.

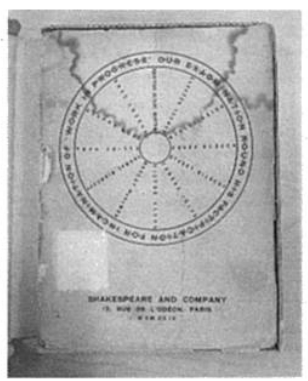

Barbara McIntosh 


\section{Bibliography}

Allen, Maryellen. "Promoting Critical Thinking Skills in Online Information Literacy Instruction Using a Constructivist Approach." College \& Undergraduate Libraries 15, no. 1-2 (2008): 21-38.

Alvarez, Pablo. "Introducing Rare Books into the Undergraduate Curriculum." RBM: A Journal of Rare Books, Manuscripts, and Cultural Heritage 7, no. 2 (Fall 2006): 94-103.

American Library Association. "Guidelines: Competencies for Special Collections Professionals” (2017). Accessed November 28, 2018. http:/ / www.ala.org/acrl/ standards/comp4specollect.

Anderberg, Lindsay. "STEM Undergraduates and Archival Instruction: A Case Study at NYU Polytechnic School of Engineering." The American Archivist 78, no. 2 (Fall/Winter 2015): 548-66.

Apedoe, Xornam S., Sally E. Walker, and Thomas C. Reeves. "Integrating Inquirybased Learning into Undergraduate Geology.” Journal of Geoscience Education 54, no. 3 (May 2006): 414-21.

Association of American Colleges and Universities. "High-Impact Educational Practices” (2008). Accessed September 8, 2019. https: / /www.aacu.org/sites/ default/files/files/LEAP/HIP_tables.pdf.

Association of College \& Research Libraries. "Guidelines for University Library Services to Undergraduate Student” (2013). Accessed November 28, 2018. http: / / www.ala.org/acrl/standards/ulsundergraduate.

ACRL RBMS-SAA Joint Task Force on the Development of Guidelines for Primary Source Literacy. "Guidelines for Primary Source Literacy" (2017). Accessed January 27, 2019. https: / / www2.archivists.org/standards/guidelines-forprimary-source-literacy.

Bahde, Anne. "Taking the Show on the Road: Special Collections Instruction in the Campus Classroom." RBM: A Journal of Rare Books, Manuscripts, \& Cultural Heritage 12, no. 2 (Fall 2011): 75-88.

Bastion, Jeannette A., and Donna Webber. Archival Internships: A Guide for Faculty, Supervisors, and Students. Chicago, IL: Society of American Archivists, 2008.

Bladek, Marta, and Karen Okamoto. "What's Theory Got to Do with It? Applying Educational Theory and Research to Revamp Freshman Library Workshops." College \& Undergraduate Libraries 21, no. 1 (January-March 2014): 19-36.

Brown, Amanda H., Barbara Losoff, and Deborah R. Hollis. "Science Instruction through the Visual Arts in Special Collections." portal: Libraries \& the Academy 14, no. 2 (April 2014): 197-216.

Brown, Laura Clark. "Chapel Hill Diarist: The Evolution of a Theory and the Practice of Immersion in Primary Sources." Journal for the Society of North Carolina Archivists 6, no. 2 (Winter 2009): 5-25.

Carini, Peter. "Archivists as Educators: Integrating Primary Sources into the Curriculum." Journal of Archival Organization 7, no. 1/2 (January-June 2009): 41-50.

Chen, Xi. "Hidden Gems Uncovered—Discovering China Studies Special Collec- 
tions in Liberal Arts Colleges in the U.S." Journal of East Asian Libraries 160 (February 2015): 54-58.

Cohen, Nadine, Liz Holdsworth, John M. Prechtel, Jill Newby, Yvonne Mery, Jeanne Pfander, and Laurie Eagleson. "A Survey of Information Literacy Credit Courses in US Academic Libraries." Reference Services Review 44, no. 4 (2016): 564-82.

Cooperstein, Susan E., and Elizabeth Kocevar-Weidinger. "Beyond Active Learning: A Constructivist Approach to Learning." Reference Services Review 32, no. 2 (2004): 141-48.

Dahl, Candice. "Creating Undergraduate Internships for non-LIS Students in Academic Libraries." Collaborative Librarianship 3, no. 2 (2011): 73-78.

Denda, Keya, and Jennifer Hunter. "Building 21st Century Skills and Creating Communities: A Team-based Engagement Framework for Student Employment in Academic Libraries." Journal of Library Administration 56, no. 3 (2016): 251-65.

Ewig, Rick. "When Did Sacajawea Die Anyway? Challenging Students with Primary Sources." In Past or Portal, Enhancing Undergraduate Learning through Special Collections and Archives. Edited by Eleanor Mitchell, Peggy Seiden, and Suzy Taraba. Chicago, IL: American Library Association, 2012.

Framework for Information Literacy for Higher Education. Chicago, IL: Association of College and Research Libraries, 2015.

Galbraith, Steven K., and Geoffrey D. Smith. Rare Book Librarianship: An Introduction and Guide. Santa Barbara, CA: Libraries Unlimited, 2012.

Gardner, Julia, and David Pavelich. "Teaching with Ephemera." RBM: A Journal of Rare Books, Manuscripts, \& Cultural Heritage 9, no. 1 (Spring 2008): 86-92.

Germek, George. "Starting Almost from Scratch: Developing Special Collections as a Teaching Tool in the Small Academic Library." College \& Undergraduate Libraries 23, no. 4 (2016): 400-13.

Hayes-Bohanan, Pamela. "Librarian Mentoring of an Undergraduate Research Project.” Journal of Library Innovation 4, no. 1 (2013): 21-28.

Hepworth, Mark, and Geoff Walton. Teaching Information Literacy for Inquiry-Based Learning. Oxford, UK: Chandos Publishing, 2009.

Hufford, Jon R. "Librarians as Mentors in an Undergraduate Research Program." Journal of Library Administration 57, no. 7 (October 2017): 776-88.

Kelly, Katy, Colleen Hoelscher, and Heidi Gauder. "Results for Resumes: Managing Undergraduate Library Interns.” Library Leadership \& Management 28, no. 4 (2014): 1-17.

Kemp, Jane. "Isn’t Being a Librarian Enough? Librarians as Classroom Teachers." College \& Undergraduate Libraries 13, no. 3 (2006): 3-23.

Kopp, Maggie G. "Internships in Special Collections: Experiential Pedagogy, Intentional Design, and High-Impact Practice.” RBM: A Journal of Rare Books, Manuscripts, \& Cultural Heritage 14, no. 2 (Spring 2019): 12-27.

Kopp, Maggie G., and John M. Murphy. "Mentored Learning in Special Collections: Undergraduate Archival and Rare Books Internships.” Journal of Library Innovation 3, no. 2 (2012): 50-62. 
Kuh, George D. High Impact Educational Practices: What They Are, Who Has Access to Them, and Why They Matter. Washington, DC: Association of American Colleges and Universities, 2008.

Lane, Anne Marie. "Books IN History; Books AS History: Teaching Undergraduates in the Toppan Rare Books Library, University of Wyoming." In Past or Portal, Enhancing Undergraduate Learning through Special Collections and Archives. Edited by Eleanor Mitchell, Peggy Seiden, and Suzy Taraba. Chicago, IL: American Library Association, 2012.

Lee, Marta K. Mentoring in the Library: Building for the Future. Chicago, IL: American Library Association, 2011.

Madway, Lorraine. "Archival Internships: Creating Real World Learning Beyond the Classroom." Kansas Library Association College and University Libraries Section Proceedings 1, no. 1 (2011): 48-56.

Manning, Mary, and Judy Silva. "Dual Archivist/Librarians: Balancing the Benefits and Challenges of Diverse Responsibilities." College \& Research Libraries 73, no. 2 (March 2012): 164-81.

Marcum, James. "The Library as Inquiry Learning System: Defining the Issues." College \& Undergraduate Libraries 16, no. 4 (October/December 2009): 358-62.

Martin-Bowtell, Adele, and Rebekah Taylor. "A Collaborative Approach to the Use of Archives in Information Literacy Teaching and Learning in an Arts University.” Art Libraries Journal 39, no. 4 (2014): 27-32.

Maypole, Joanne, and Timothy Gray Davies. "Students' Perceptions of Constructivist Learning in a Community College American History II Survey Course." Community College Review 29, no. 2 (Fall 2001): 54-79.

McCoy, Michelle. "The Manuscript as Question: Teaching Primary Sources in the Archives-the China Missions Project." College \& Research Libraries 71, no. 1 (January 2010): 49-62.

Mestre, Lori S., and Jessica M. Lecrone. "Elevating the Student Assistant: An Integrated Development Program for Student Library Assistants." College and Undergraduate Libraries 22, no. 1 (2015): 1-20.

Mery, Yvonne, Jill Newby, and Ke Peng. "Why One-Shot Information Literacy Sessions Are Not the Future of Instruction: A Case for Online Credit Courses." College \& Research Libraries 73, no. 4 (July 2012): 366-77.

Mitchell, Eleanor, Peggy Seiden, and Suzy Taraba. Past or Portal? Enhancing Undergraduate Learning through Special Collections and Archives. Chicago, IL: Association of College \& Research Libraries, 2012.

Morris, Sammie L., Tamar Chute, and Ellen Swain. "Teaching with Archives: A Guide for Archivists, Librarians, and Educators." In Teaching with Primary Sources. Edited by Christopher J. Prom and Lisa Janicke Hinchliffe. Chicago, IL: Society of American Archivists, 2016.

Morris, Sammie L., Lawrence J. Mykytiuk, and Sharon A. Weiner. "Archival Literacy for History Students: Identifying Faculty Expectations of Archival Research Skills." The American Archivist 77, no. 2 (Fall/Winter 2014): 394-424. 
Nimer, Cory L., and J. Gordon Daines. "Teaching Undergraduates to Think Archivally." Journal of Archival Organization 10, no. 1 (January-March 2012): 4-44.

Nutefall, Jennifer E. "Structuring a Successful Instruction Internship." College \& Undergraduate Libraries 19, no. 1 (2012): 80-94.

Passoneau, Sarah, and Michele Christian. "Participant Learning in an Archival Education and Outreach Program to Fraternities and Sororities: An Implementation of Evidence-Based Librarianship and Information Science." RBM: A Journal of Rare Books, Manuscripts, \& Cultural Heritage 14, no. 2 (Fall 2013): 92-110.

Prom, Christopher, and Lisa Janicke Hinchliffe. Teaching with Primary Sources. Chicago, IL: Society of American Archivists, 2016.

Randall, Tresa. "Enlivening Dance History Pedagogy through Archival Projects." Journal of Dance Education 12, no. 1 (2012): 7-13.

Reale, Michelle. "Critical Pedagogy in the Classroom: Library Instruction that Gives Voice to Students and Builds a Community of Scholars." Journal of Library Innovation 3, no. 2 (September 2012): 80-88.

Reynolds, Matthew C. "Lay of the Land: The State of Bibliographic Instruction Efforts in ARL Special Collections Libraries.” RBM: A Journal of Rare Books, Manuscripts, \& Cultural Heritage 13, no. 1 (Spring 2012): 13-26.

Robyns, Marcus. "The Archivist as Educator: Integrating Critical Thinking Skills into Historical Research Methods Instruction.” The American Archivist 64, no. 2 (Fall 2001): 363-84.

Rockenbach, Barbara. "Archives, Undergraduates, and Inquiry-Based Learning: Case Studies from Yale University Library." The American Archivist 74, no. 1 (Spring/Summer 2011): 297-311.

Roff, Sandra. "Archives, Documents, and Hidden History: A Course to Teach Undergraduates the Thrill of Historical Discovery Real and Virtual." History Teacher 40, no. 4 (August 2007): 551-58.

Sauceda, Jonathan. 'Arranging 'The Library of Babel': Special Collections, Undergraduate Research, and Librarian Engagement." portal: Libraries and the Academy 18, no. 2 (April 2018): 391-408.

Schmiesing, Ann, and Deborah Hollis. "The Role of Special Collections Departments in Humanities Undergraduate and Graduate Teaching: A Case Study." portal: Libraries \& the Academy 2, no. 3 (July 2002): 465-80.

Schreyer, Alice D. "What's So Special about Special Collections Librarians?" RBM: A Journal of Rare Books, Manuscripts, \& Cultural Heritage 7, no. 1 (Spring 2006): 49-54.

Smith, Steven E. 'From 'Treasure Room' to 'School Room': Special Collections and Education.” RBM: A Journal of Rare Books, Manuscripts, \& Cultural Heritage 7 , no. 1 (Spring 2006): 31-39.

Sobel, Karen, Peter Ramsey, and Galin Jones. "The Professor-Librarian: Academic Librarians Teaching Credit-Bearing Courses.” Public Services Quarterly 14, no. 1 (January-March 2018): 1-21. 
Stam, Deirdre. "Bridge That Gap! Education and Special Collections." RBM: A Journal of Rare Books, Manuscripts, \& Cultural Heritage 7, no. 1 (Spring 2006): 16-30.

Using Primary Sources: Hands-on Instructional Exercises. Edited by Anne Bahde, Heather Smedberg, and Mattie Taormina. Santa Barbara, CA: ABC-CLIO, 2014.

Vassilakaki, Evgenia, and Valentini Moniarou-Papaconstantinou. "Beyond Preservation: Investigating the Roles of Archivists.” Library Review 66, no. 3 (2017): $110-26$.

Vong, Silvia. "A Constructivist Approach for Introducing Undergraduate Students to Special Collections and Archival Research." RBM: A Journal of Rare Books, Manuscripts, \& Cultural Heritage 26, no. 2 (Fall 2016): 148-71.

Walsh, John. Information Literacy Instruction: Selecting an Effective Model. Oxford, UK: Chandos, 2011.

Wiebe, Todd J. "The Library and Undergraduate Research in the Liberal Arts: Present Contributions and Future Opportunities." Undergraduate Libraries 23, no. 3 (July-September 2016): 223-51.

Yakel, Elizabeth, and Doris Malkmus. "Contextualizing Archival Literacy.” In Teaching with Primary Sources. Edited by Christopher J. Prom and Lisa Janicke Hinchliffe, 5-67. Chicago, IL: Society of American Archivists, 2016.

York, Amy, Christy Groves, and William Black. "Enriching the Academic Experience: The Library and Experiential Learning." Collaborative Librarianship 2, no. 4 (2010): 193-203.

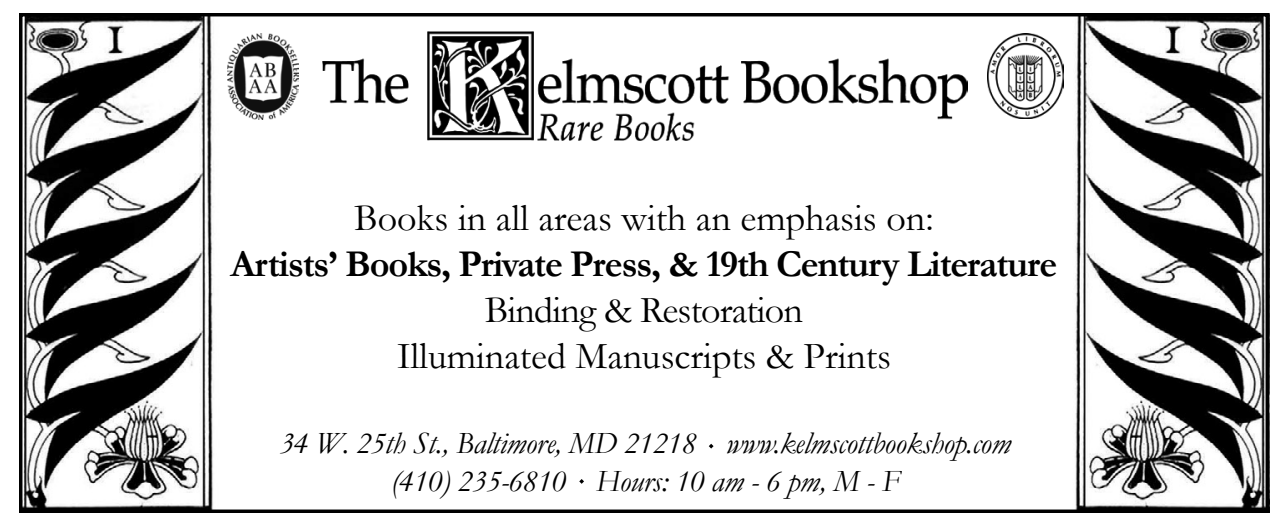

